\title{
UJI EFIKASI EKSTRAK DAUN DAN BIJI DARI TANAMAN SUREN, MIMBA DAN SIRSAK TERHADAP MORTALITAS HAMA ULAT GAHARU
}

\author{
The Application of Leaf and Seed Extraction of Suren, \\ Mimba and Soursop to Mortality for Gaharu Pest \\ Fajar Lestari ${ }^{1)}$ dan/and Wida Darwiati ${ }^{2)}$ \\ 1) Balai Penelitian Kehutanan Banjarbaru, Kalimantan Selatan \\ Jl. A.Yani Km 28,7 Landasan Ulin, Banjarbaru, Kalimantan Selatan \\ Telp./Fax. 0511-4707872 \\ Email: fajar@foreibanjarbaru.or.id \\ 2) Pusat Penelitian dan Pengembangan Peningkatan Produktivitas Hutan \\ Kampus Balitbang Kehutanan, Jl. Gunung Batu No. 5, Bogor 16118 \\ Telp. 0251-8631238, Fax. 0251-7520005 \\ Email: wdarwiati@yahoo.com
}

Naskah masuk : 7 Oktober 2013; Naskah diterima : 22 Oktober 2014

\begin{abstract}
The use of chemical pesticide has been limited considering its negative impact for the environment. Information about biological insecticide as worm Heortia vitessoides pest of agarwood is still limited. This research aimed to determine biological insecticide effectiveness of leaves and seed of suren, neem, and soursop as $\mathrm{H}$. vitessoides worm controler. The research has been conducted in Forest Protection Laboratory of Forestry Research Institute of Banjarbaru. Researh used complete random design with 6 treatments and 3 replications. Research result showed that seed extract indicated high effect of insecticide compared to leaves. The highest mortality occurred on neem seed extract with concentration of $3 \%$ and $4 \%$, and soursop seed extract of $4 \%$ concentration caused mortality of $\mathrm{H}$. vitessoides larva as $100 \%$, while on suren seed extract of $4 \%$ concentration mortality occurred as $53.33 \%$. Type and concentration of insecticide had a significant effect on $\mathrm{H}$. vitessoides larva mortality.
\end{abstract}

Keywords: H. vitessoides, biological insecticide, neem, soursop, suren

\begin{abstract}
ABSTRAK
Penggunaan pestisida kimia dewasa ini mulai dibatasi, mengingat dampak negatif yang ditimbulkan terutama bagi lingkungan. Informasi tentang insektisida nabati sebagai pengendali hama ulat daun gaharu Heortia vitessoides masih terbatas. Penelitian ini bertujuan mengetahui efektifitas insektisida nabati ekstrak daun dan biji tanaman suren, mimba dan sirsak sebagai pengendali ulat $H$. vitessoides. Penelitian dilakukan di Laboratorium Perlindungan Hutan, Balai Penelitian Kehutanan Banjarbaru. Penelitian menggunakan Rancangan Acak Lengkap dengan 6 perlakuan 3 ulangan. Hasil penelitian menunjukkan bahwa ekstrak biji memberikan efek insektisidal tinggi dibandingkan dengan daun. Mortalitas paling tinggi terjadi pada perlakuan ekstrak biji mimba konsentrasi 3\% dan $4 \%$ serta ekstrak biji sirsak konsentrasi $4 \%$ yang menyebabkan mortalitas larva $H$. vitessoides sebesar $100 \%$, sedangkan ekstrak biji suren konsentrasi $4 \%$ memberikan efek mortalitas sebesar 53,33\%. Jenis insektisida dan konsentrasi berpengaruh nyata terhadap mortalitas larva $H$. vitessoides.
\end{abstract}

Kata kunci: $H$. vitessoides, insektisida nabati, mimba, sirsak, suren

\section{PENDAHULUAN}

\section{A. Latar Belakang}

Tanaman gaharu (Aquilaria malaccensis) merupakan tanaman hutan yang menghasilkan hasil hutan bukan kayu (HHBK) yang bernilai ekonomi tinggi. Tanaman ini dapat memproduksi gubal gaharu yang aromanya harum, mengandung damar wangi (aromatik resin) sebagai akibat adanya serangan jamur. Gubal gaharu sebagai komoditi elit bermanfaat untuk keperluan industri parfum, kosmetik, tasbih dan obat-obatan. Pemanfaatan gaharu dilakukan dengan cara penebangan pohon sehingga kelestarian tegakan gaharu secara teknis perlu didukung oleh upaya pembudidayaan (Anwar \& Hartal, 2007). Keberhasilan budidaya tanaman gaharu dapat dilakukan dengan menjaga tanaman 
dari kerusakan yang disebabkan oleh adanya serangan hama daun jenis Heortia vitessoides. Serangan hama ini mengganggu pertumbuhan terutama sejak tanaman berumur satu tahun sampai dengan enam tahun. Ulat menyerang daun gaharu dengan cara memakan pucuk tanaman dan daun muda, bahkan menyerang daun tua, sehingga berakibat tanaman menjadi gundul. Ulat membentuk koloni dalam menyerang tanaman sehingga bagian tanaman khususnya daun dan batang muda habis dalam waktu yang singkat. Persentase serangan hama ini dapat mencapai 41\% (Lestari \& Suryanto, 2010).

Serangan ulat dari jenis $H$. vitessoides ini dapat terjadi dua kali dalam satu tahun. Serangan pertama daun yang rontok masih bisa tumbuh lagi, namun saat terkena serangan yang berikutnya tanaman langsung mati karena kecepatan tumbuh tanaman lebih lambat dibandingkan dengan pertumbuhan populasi ulat. Oleh karena itu wabah hama ulat ini dianggap sangat meresahkan dan merugikan petani gaharu. Salah satu pemecahan dari masalah tersebut adalah adanya upaya pengendalian.

Dewasa ini mulai digalakkan pengendalian yang ramah lingkungan salah satunya dengan memanfaatkan tanaman yang menghasilkan insektisida nabati contohnya tanaman mimba, suren dan sirsak. Insektisida nabati mempunyai bahan dasar berupa bahan aktif metabolit sekunder yang berasal dari tumbuh-tumbuhan. Bahan aktif tersebut berguna sebagai sarana pertahanan diri dari organisme yang menyerang tumbuhan tersebut. Hal ini menunjukkan bahwa metabolit sekunder tumbuhan mempunyai potensi untuk digunakan sebagai bahan-bahan perlindungan tanaman (Dadang \& Prijono, 2008).

Beberapa tumbuhan yang mempunyai potensi sebagai insektisida nabati diantaranya yang berasal dari famili Meliaceae seperti mimba (Azadirachta indica), Suren (Toona sinensis), Aglaia, Cedrela, Chisocheton, Dysoxylum, Khaya, Swietenia, Turrea dll (Isman et al., 1995 dalam Dadang $\&$ Prijono, 2008). Famili lain yang mempunyai potensi dikembangkan sebagai agen pengendali dari famili Annonacea seperti Annona muricata, A. glabra, A. montana. Berdasarkan hasil penelitian diperoleh bahwa beberapa species dari famili ini mempunyai aktivitas biologi yang cukup tinggi terhadap berbagai species serangga hama (Dadang \& Prijono, 2008).

Pemanfaatan tumbuhan untuk pengendalian hama perlu diujicobakan guna mengetahui efektivitas dan toksisitas metabolit sekunder terhadap serangan hama pada tanaman. Penelitian ini me- nguji keefektifantiga jenis tanaman insektisida nabati nabati (mimba, suren dan sirsak) dalam mengendalikan hama daun yang menyerang tanaman gaharu.

\section{B. Tujuan Penelitian}

Penelitian ini bertujuan untuk menguji efektifitas dari ekstrak daun dan biji mimba, suren dan sirsak terhadap mortalitas hama daun gaharu dari jenis $H$. vitessoides pada skala laboratorium.

\section{METODOLOGI}

\section{A. Tempat dan waktu}

Penelitian dilaksanakan di Laboratorium Perlindungan Hutan Balai Penelitian Kehutanan (BPK) Banjarbaru, Kalimantan Selatan. Penelitian dilakukan pada bulan Desember 2012 sampai Maret 2013.

\section{B. Bahan dan Alat}

Bahan yang digunakan dalam penelitian adalah hama daun jenis ulat $H$. vitessoides instar pertama, daun gaharu muda sebagai pakan ulat, daun dan bji mimba, suren dan sirsak. Adapun alat yang digunakan berupa disseting set, kurungan serangga, kertas saring, botol kaca, pisau, cawan petri, gelas ukur, masker, aquades, kain kasa, sarung tangan, sprayer, kamera, blender dan lain-lain.

\section{Metode}

Parameter yang diamati pada uji coba pengendalian ini adalah jumah ulat yang mati serta waktu yang dibutuhkan untuk mencapai kematian. Uji coba pengendalian dilakukan dengan merendam daun gaharu pada larutan ekstrak daun dan biji dari tanaman mimba, suren dan sirsak yang digunakan sebagai pakan hama uji.

\section{Eksplorasi hama daun ulat $\boldsymbol{H}$. vitessoides}

Larva instar pertama diperoleh dari tanaman gaharu di Desa Gumbil, Kandangan, Kalimantan Selatan. Larva langsung digunakan sebagai serangga uji karena upaya rearing/perbanyakan di laboratorium belum berhasil.

\section{Pembuatan ekstrak daun dan biji tanam- an mimba, suren dan sirsak}

Bahan daun dan biji yang telah disiapkan selanjutnya ditimbang masing-masing $1 \mathrm{~kg}$. Daun yang telah ditimbang dipotong kecil atau dicacah 
tetapi tidak sampai halus, sedangkan untuk perlakuan biji ditumbuk sampai halus untuk memudahkan proses ekstraksi, karena semua bahan ekstrak menggunakan alat blender dan air sebagai pelarutnya. Hasil dari ekstraksi kemudian disaring atau diperas dengan kain kasa untuk mendapatkan larutan yang bersih dan disimpan pada botol yang sudah diberi label.

\section{Prosedur penelitian}

Pengujian dilakukan dengan merendam daun gaharu sebanyak lima helai dalam ekstrak daun dan biji mimba, suren dan sirsak. Konsentrasi ekstrak yang digunakan adalah $0,3 \mathrm{~g} / 1$ air (3\%) dan $0,4 \mathrm{~g} / 1$ air (4\%). Perlakuan berupa pemberian daun gaharu sebagai pakan larva $H$. vitessoides diulang sebanyak 3 kali dan setiap ulangan menggunakan lima larva. Dengan demikian akan diperoleh 12 kombinasi perlakuan yang diulang 3 kali, dengan masing-masing ulangan menggunakan 5 larva, sehingga diperlukan 180 larva. Daun gaharu sebagai pakan direndam pada ekstrak selama kurang lebih 3 menit, kemudian daun tersebut diangkat dan dikeringanginkan selanjutnya diletakkan pada cawan petri yang telah dilapisi kertas saring dan berisi larva $H$. vitessoides. Larva dibiarkan memakan daun tersebut selama 48 jam (2 hari), selanjutnya larva dipindahkan dan diberi daun yang segar kemudian diinkubasikan hingga mencapai mortalitas atau menjadi pupa/ imago. Penentuan efektivitas sifat insektisida dihitung dari mortalitas larva setelah 7 hari perlakuan (Asmaliyah et al., 2006). Persentase mortalitas larva dihitung setiap hari selama 7 hari pada setiap perlakuan dengan rumus:

Mortalitas larva $(\%)=\frac{\sum \text { larva yang mati }}{\Sigma \text { larva }} \times 100 \%$

Menurut Prijono (1998), aktifitas insektisida ekstrak diklasifikasikan dalam beberapa kategori yaitu: 1) aktifitas kuat: mortalitas (m) $\geq 95 \%$, 2) agak kuat: $75 \% \leq \mathrm{m}<95 \%, 3)$ cukup kuat: $60 \% \leq \mathrm{m}<75 \%, 4)$ sedang: $40 \% \leq \mathrm{m}<60 \%, 5$ ) agak lemah: $25 \% \leq \mathrm{m}<40 \%, 6$ ) lemah: $5 \% \leq \mathrm{m}<$ $25 \%, 7)$ tidak aktif: $\mathrm{m}<5 \%$.

Penggunaan air sebagai kontrol pada penelitian ini tidak digunakan sebagai perlakuan. Hal ini dilakukan karena larva/ulat yang dipergunakan untuk aplikasi insektisida telah melalui tahap aklimatisasi. Aklimatisasi larva merupakan suatu upaya penyesuaian fisiologis agar dapat beradaptasi terhadap kondisi lingkungan yang baru dalam hal ini kondisi laboratorium. Upaya tersebut menghindarkan kematian larva akibat kon- disi lingkungan laboratorium tetapi kematian larva/ ulat disebabkan hanya oleh aplikasi perlakuan insektisida.

\section{Analisis Data}

Pengolahan data berdasarkan hasil di laboratorium dan rancangan yang dipakai adalah rancangan acak lengkap dengan dua faktor (rancangan acak lengkap faktorial). Faktor tersebut yakni jenis ekstrak dan konsentrasi insektisida nabati. Data hubungan antara mortalitas larva dengan konsentrasi dianalisis dengan analisis varian. Analisis dilakukan terhadap jenis dan konsentrasi sebagai faktor tunggal dan interaksi kedua faktor tersebut. Uji Duncan (Duncan Multiple Range Test: DMRT) dilakukan apabila terjadi perbedaan yang nyata pada masing-masing faktor yang dicobakan. Analisis menggunakan program SPSS 15.

\section{HASIL DAN PEMBAHASAN}

\section{A. Pengaruh Ekstrak Daun dan Biji Suren terhadap Mortalitas Larva H. vitessoides}

Kematian larva rata-rata dimulai dari hari pertama perlakuan sudah menunjukkan adanya respon dan relatif konstan sampai hari ke tujuh. Perlakuan ekstrak biji suren dengan konsentrasi 4\% lebih cepat mematikan dibanding perlakuan lainnya, mortalitas larva terlihat sejak hari pertama sampai hari kelima yaitu dari 6,67\%sampai $10 \%$ dan akhirnya mencapai $53,33 \%$ pada pengamatan hari ke tujuh. Mortalitas larva pada perlakuan ekstrak biji suren 3\% dicapai pada hari ke dua sebesar $20 \%$ kemudian meningkat pada hari ke tiga sampai hari ke tujuh sebesar 40\%. Sementara, perlakuan ekstrak daun suren daun $4 \%$ menyebabkan mortalitas larva sebesar $6,67 \%$ pada hari ke tiga sampai hari ke tujuh, sedangkan perlakuan ekstrak daun suren 3\% larva tidak menunjukkan tanda kematian hanya tingkah laku yang sudah lemah dan tidak ada aktivitasnya (Gambar 1).

Secara umum, gejala kematian pada larva $H$. vitessoides terlihat sejak hari pertama yang ditandai dengan adanya perubahan warna ulat yaitu dari hijau segar (Gambar 2A) menjadi kekuningkuningan. Perubahan warna tersebut seiring dengan perubahan perilaku ulat yaitu ulat cenderung tidak aktif / tidak bergerak, namum apabila disentuh ulat masih hidup. Aktivitas makan pun mulai menurun hal ini diindikasikan dengan sedi- 
kitnya daun yang dimakan dan lama kelamaan ulat akan mati yang ditandai dengan perubahan warna ulat menjadi cokelat dan kepala berwarna hitam dengan tubuh mengecil dan lunak(Gambar 2).

Insektisida nabati yang termakan serangga dalam konsentrasi yang tepat secara langsung dapat menyebabkan mortalitas, sedangkan pada konsentrasi yang tidak mematikan (subletal), insektisida hanya mempengaruhi perilaku dan fisiologi serangga saja. Aktivitas penghambatan pada aktivitas/ daya makan (antifeedant) merupakan salah satu contoh gangguan perilaku, sedangkan gangguan fisiologis di antaranya dapat berupa aktivitas penghambatan pertumbuhan melalui gangguan terhadap aktivitas enzim pencernaan, misalnya enzim protease dan invertase (Dadang \& Prijono, 2008).

Tanaman suren (Toona sinensis) diketahui mengandung bahan aktif surenin, surenon dan surenolakton. Ketiga bahan aktif tersebut berfungsi se- bagai insektisida yang berperan dalam penghambat pertumbuhan dan antifeedant (penghambat daya makan) larva ulat sutera. Selain itu juga, Suren terbukti sebagai anti repellant (pengusir/ penolak) serangga (Jayusman, 2006). Ekstrak daun suren pernah diujicobakan untuk mengendalikan hama ulat jengkal pada tanaman sengon, namun hasil yang ditunjukkan belum efektif dengan penurunan intensitas serangan dan derajat kerusakan rata-rata $0,19 \%$ dan 1,4\% (Dendang et al., 2007). Sementara ekstrak biji suren dapat menyebabkan kematian ulat Eurema sp. (Asmaliyah, 2010; Darwiati, 2013) dan Spodoptera litura sebesar 98\% dan 42\% (Asmaliyah et al., 2010). Hasil penelitian Darwiati (2013) menunjukkan kematian larva Eurema sp. oleh ekstrak biji suren tidak terkait dengan gangguan fungsi sistem hormon perkembangan serangga karena larva tersebut tidak mengalami perubahan bentuk.

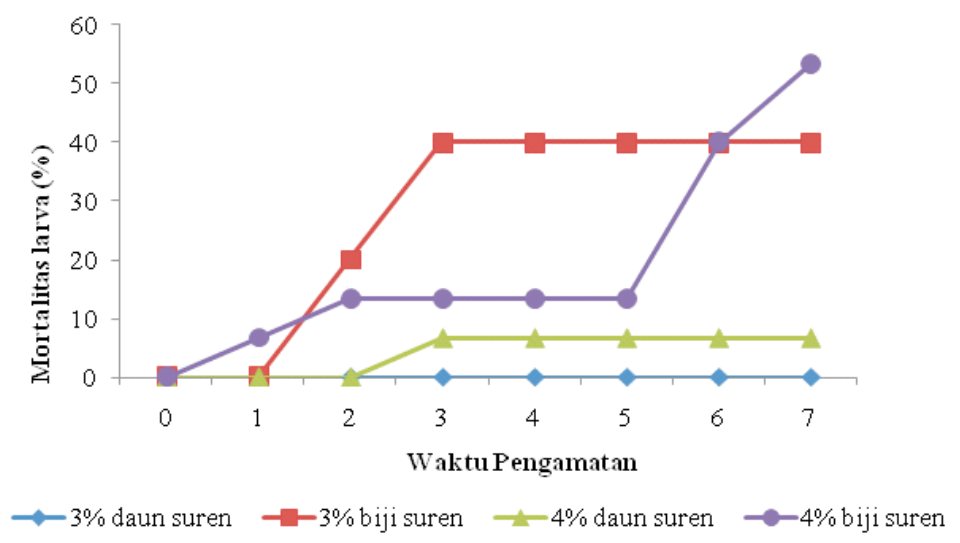

Gambar(Figure) 1. Mortalitas larva H. vitessoides selama tujuh hari pengamatan pada perlakuan ekstrak daun dan biji suren (H. vitessoides mortality during for seven days observation extracts treatment of suren's leaf and seed)
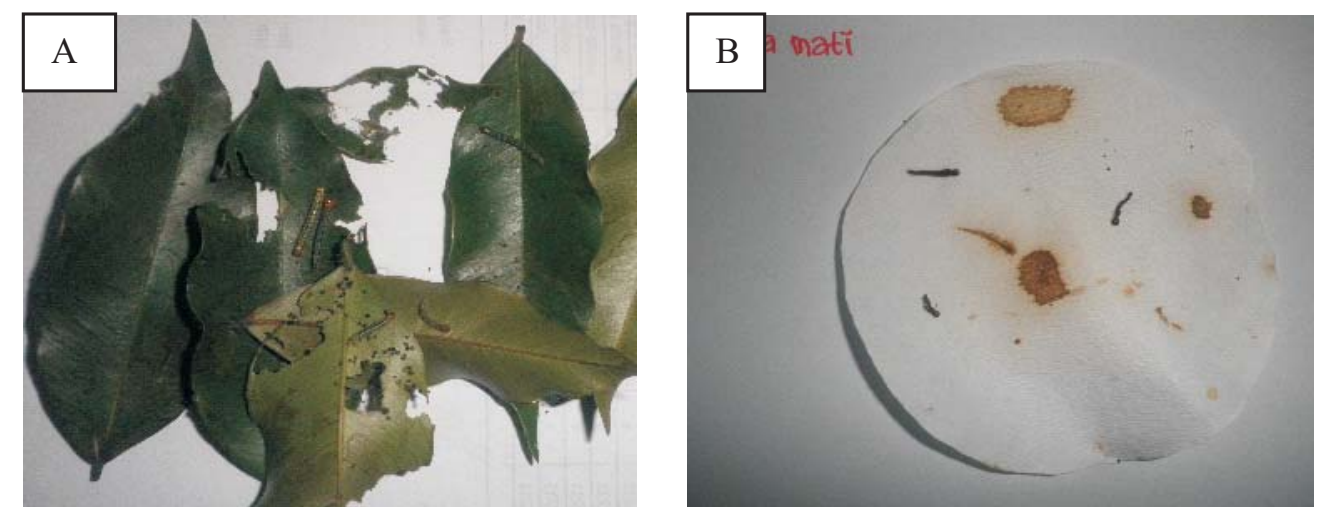

Gambar (Figure) 2. (A) Hama ulat H. vitessoides berwarna hijau segar (Live green colored $\mathrm{H}$. Vitessoides worm pest), (B) Larva mati akibat memakan daun yang telah direndam di larutan (Dead larva caused by eating soaked in a solution) 


\section{B. Pengaruh Ekstrak Daun dan Biji Sirsak terhadap Mortalitas Larva $\boldsymbol{H}$. vitessoides}

Kematian larva pada perlakuan ekstrak daun dan biji sirsak ini terjadi sejak hari pertama perlakuan (24 jam), kemudian ada peningkatan jumlah mortalitas yang relatif tetap sampai dengan hari ke tujuh. Mortalitas paling tinggi terjadi pada perlakuan ekstrak biji sirsak konsentrasi 4\%pada hari ke tujuh sebesar $100 \%$, sedangkan pada hari yang sama perlakuan ekstrak daun sirsak konsentrasi 3\% mortalitas larva hanya sebesar 20\% (Gambar 3).

Penelitian uji pengendalian dengan mengunakan ekstrak daun sirsak pernah dilakukan terhadap hama pemakan pucuk pulai darat Clouges glauculalis di Palembang. Mortalitas larva pada ujicoba tersebut sebesar 33,33\% (Asmaliyah et al.,
2006). Hasil penelitian Asmaliyah \& Anggraeni (2009) diperoleh bahwa ekstrak daun sirsak efektif mengendalikan ulat kantong (Plagodiella sp.) dan hama daun pada tanaman mangrove sebesar $25,32 \%$, sedangkan perlakuan ekstrak daun mimba dan sirsak hanya mampu menekan perkembangan hama daun tanaman mangrove sebesar $12,98 \%$.

\section{Pengaruh Ekstrak Daun dan Biji Nimba terhadap Mortalitas Larva $\boldsymbol{H}$. vitessoides}

Perlakuan ekstrak mimba menunjukkan bahwa daun dan biji mempunyai sifat insektisidal terhadap larva $H$. vitessoides. Perlakuan biji mimba pada penelitian ini dengan konsentrasi 3\% menyebabkan mortalitas larva $100 \%$ pada hari ke tujuh dan konsentrasi 4\% menyebabkan mortalitas $100 \%$ pada hari ke tiga.

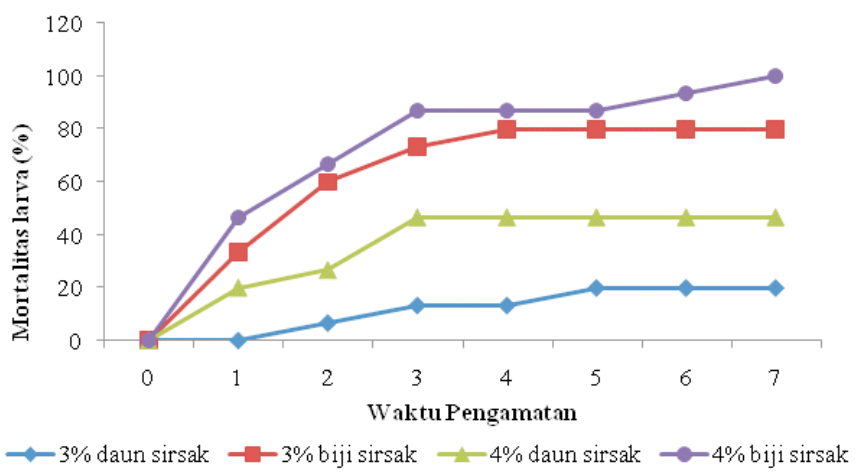

Gambar(Figure) 3. Mortalitas larva H. vitessoides selama tujuh hari pengamatan pada perlakuan ekstrak daun dan biji sirsak (H. vitessoides mortality during for seven days observation extracts treatment of sirsak's leaf and seed)

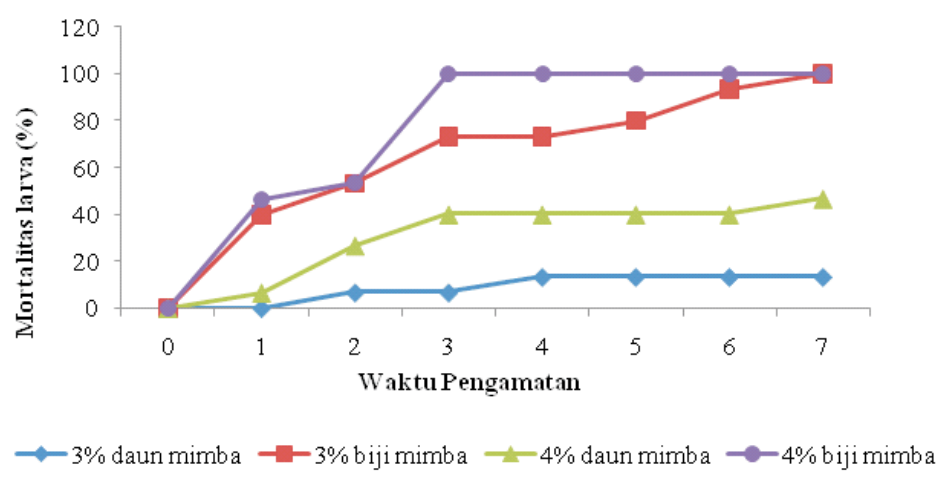

Gambar(Figure) 4. Mortalitas larva H. vitessoides selama tujuh hari pengamatan pada perlakuan ekstrak daun dan biji mimba $(\mathrm{H}$. vitessoides mortality during for seven days observation extracts treatment of neem's leaf and seed) 
Semua bagian tanaman mimba (Azadirachta indica) mengandung azadirachtin, meliantrol, slanin, nimbin. Bahan aktif tersebut paling tinggi kandungannya pada biji. Bahan aktif dari tanaman mimba mampu mengendalikan sekitar $127 \mathrm{je}-$ nis hama dan mampu berperan sebagai fungisida, bakterisida, antivirus, nematisida serta moluskisida. Kematian hama sebagai akibat dari penggunaan insektisida dari tanaman mimba terjadi pada pergantian instar berikutnya atau pada proses metamorfosis, namun efeknya tidak membunuh hama secara cepat. Efek yang terlihat adalah pada penghambatan daya makan, pertumbuhan, daya reproduksi, proses ganti kulit, perkembangan menjadi serangga dewasa, daya tetas telur, pembentukan kitin, serta gangguan pada proses perkawinan (Anggraeni et al., 2010). Selain itu, hasil penelitian lain menunjukkan senyawa mimba mampu menghambat aktivitas dan perilaku makan pada hama daun Tuta absoluta (Tome et al., 2013), menghambat perkembangan pascaembrio dan kekebalan tubuh larva instar kelima jenis Plodia interpunctella (Lynn et al., 2012).

\section{Perbandingan Hasil Ekstrak Daun dan Biji dari Tanaman Suren, Mimba dan Sirsak}

Hasil penelitian menunjukkan bahwa jenis insektisida nabati dan konsentrasi yang digunakan berpengaruh nyata terhadap mortalitas larva $H$. vitessoides. Hal ini ditunjukkan oleh hasil analisis sidik ragam, jenis insektisida $F_{\text {hitung(0,05, 5, 24) }}=$ $17,069>\mathrm{F}_{\text {tabel }}=2,621$; dosis perlakuan $\mathrm{F}_{\text {hitung } 0,05,1 \text {, }}$ ${ }_{24}=17,069>F_{\text {tabel }}=4,26$. Namun demikian interaksi ke dua perlakuan tidak memberikan pengaruh yang nyata $\mathrm{F}_{\text {hitung(0,05,5,24) }}=0,573>\mathrm{F}_{\text {tabel }}=2,621$. Hasil uji selang berganda duncan menunjukkan perlakuan terbaik yakni biji mimba, suren dan sirsak seperti tertera pada Tabel 1.

Miller \& Strickler (1984) mengemukakan bahwa sifat toksik senyawa tanaman terhadap serangga dapat berupa gangguan terhadap perkembangan serangga secara langsung (intrinsik) maupun tidak langsung (ekstrinsik), sedangkan efek antifeedant yang dikandung tanaman dapat dideteksi serangga melalui sistem indera (efek antifeedant primer) atau mempengaruhi syaraf pusat serangga yang mengatur proses makan (efek antifeedant sekunder). Kinerja insektisida botani dipengaruhi oleh ketahanan senyawa aktif di lapangan dan ketahanan senyawa aktif ini dipengaruhi oleh faktor lingkungan. Insektisida asal tumbuhan ini mudah terurai oleh cahaya matahari sehingga memiliki persistensi yang singkat di lapangan. Data persistensi yang tepat melalui pengukuran waktu paruh perlu diketahui agar dosis awal yang harus digunakan untuk mencapai tingkat keefektifan pengendalian yang diharapkan selama selang waktu tertentu dapat ditentukan dengan tepat. Bila dosis aplikasi suatu insektisida telah ditentukan, waktu paruh dapat digunakan untuk memperkirakan interval aplikasi insektisida tersebut.

Berdasarkan Gambar 1, 3 dan 4 hubungan mortalitas pada serangga uji (H. vitessoides) dari ketiga tanaman penghasil insektisida nabati (mimba, suren dan sirsak) ternyata pada peletakan hari pertama telah menunjukkan adanya mortalitas yang tinggi, baik pada konsentrasi yang rendah maupun tinggi pada semua ekstrak daun dan biji. Hal ini mengindikasikan adanya interaksi dari serangga uji dengan insektisida nabati yang bersifat "knock down" artinya larva dapat mengalami kelumpuhan. Kematian serangga pada perlakuan ekstrak biji diawali dengan paralysis (tungkai sudah

Tabel (Table) 1. Hasil Uji Duncan (DMRT) keragaman pengaruh insektisida nabati terhadap mortalitas larva H. vitessoides (Duncan result of effects of nabati insecticide to larva $\mathrm{H}$. vitessoides mortality)

\begin{tabular}{lccc}
\hline No & $\begin{array}{c}\text { Bagian tanaman } \\
(\text { Partorgan })\end{array}$ & $\begin{array}{c}\text { Jenis pestisida } \\
\text { (Species) }\end{array}$ & $\begin{array}{c}\text { Mortalitas (\%) } \\
(\text { Mortality) }\end{array}$ \\
\hline 1. & Daun & Suren & $3,33^{\mathrm{a}}$ \\
2. & Daun & Mimba & $30,0^{\mathrm{ab}}$ \\
3. & Daun & Sirsak & $33,33^{\mathrm{ab}}$ \\
4. & Biji & Suren & $46,67^{\mathrm{b}}$ \\
5. & Biji & Sirsak & $100^{\mathrm{c}}$ \\
6. & Biji & Mimba & $100^{\mathrm{c}}$ \\
\hline
\end{tabular}

Keterangan (remarks): Rataan mortalitas yang diikuti dengan huruf yang sama menunjukkan tidak berbeda nyata berdasarkan uji selang berganda Duncan pada tingkat kepercayaan 95\% (Mean mortality value with the same latter is not significantly on Duncan's Multiple Range Test) 
tidak mampu lagi menopang tubuh), hal ini diduga karena ekstrak biji mengandung racun yang dapat melumpuhkan fungsi otot sehingga hilangnya kemampuan untuk bergerak, selain itu ekstrak biji yang mengandung minyak menempel pada bagian tubuh serangga selama pemaparan sehingga spirakel serangga tersebut tersumbat. Kemungkinan lain senyawa aktif dari ekstrak biji mempenetrasi kutikula serangga dan meresap ke dalam tubuh kemudian berakumulasi sehingga terjadi kelumpuhan dan selanjutnya mengakibatkan kematian. Namun pada pengujian dengan ekstrak daun, kematian serangga tidak terlalu tinggi. Hal ini disebabkan ekstrak daun kurang mempunyai efek mortalitas atau konsentrasi yang diberikan kurang mencapai konsentrasi yang mematikan. Efek kontak yang rendah pada suatu bahan aktif terhadap hama yang menjadi sasaran mungkin disebabkan daya penetrasi bahan aktif ekstrak yang melalui kutikula rendah atau bahan aktif yang masuk kedalam tubuh tidak pernah mencapai kadar beracun, akibat cepatnya proses ekskresi dan atau metabolisme bahan aktif di dalam tubuh serangga (Darwiati, 2009).

\section{KESIMPULAN DAN SARAN}

Ekstrak daun dan biji memberikan pengaruh yang nyata terhadap mortalitas larva $H$. vitessoides. Interaksi kedua perlakuan (daun dan biji) tidak memberikan pengaruh yang nyata terhadap mortalitas larva $H$. vitessoides. Perlakuan terbaik yakni menggunakan ekstrak biji mimba dan biji sirsak konsentrasi 0,4 gr/l air dengan mortalitas larva sebesar $100 \%$.

\section{DAFTAR PUSTAKA}

Anggraeni, I., Lelana, N.E., \& Darwiati, W. (2010). Hama penyakit dan gulma hutan tanaman. Sintesa Hasil Penelitian Hama, Penyakit dan Gulma Hutan Tanaman. Pusat Penelitian dan Pengembangan Produktivitas Hutan. Bogor.

Anwar, G., \& Hartal. (2007). Teknologi peningkatan kualitas kayu gubal gaharu (Aquilaria malaccensis lamk.) di kawasan pesisir bengkulu dengan inokulasi jamur penginduksi resin. Fakultas Pertanian. Universitas Bengkulu.
Asmaliyah, Wati, E.E., Utami, S., Mulyadi, K., Yudhistira, \& Sari, F.W. (2010). Pengenalan tumbuhan penghasil pestisida nabati dan pemanfaatannya secara tradisional. Booklet. Pusat Penelitian dan Pengembangan Produktivitas Hutan.

Asmaliyah, \& Anggraeni, I. (2009). Uji Aplikasi beberapa bioinsektisida dan kombinasinya terhadap serangan hama ulat kantong Pagidiella sp. pada bibit Rhizophora apiculata di Persemaian. Jurnal Penelitian Hutan Tanaman, Vol. 6(1): 37 - 43.

Asmaliyah, S., Utami, \& Yudhistira. (2006). Efikasi beberapa jenis insektisida terhadap hama pemakan daun pada tanaman pulai darat. Jurnal Penelian Hutan Tanaman, Vol. 3 (2): 83 - 91.

Dadang, \& Prijono, D. (2008). Insektisida nabati: Prinsip, pemanfaatan dan pengembangan. Departemen Proteksi Tanaman. Fakultas Pertanian IPB. Bogor.

Darwiati, W. (2009). Uji efikasi ekstrak tanaman suren sebagai insektisida nabati dalam pengendalian hama daun (Eurema spp. dan Spodoptera litura F). Tidak diterbitkan. Thesis. Sekolah Pasca Sarjana IPB.

Darwiati, W. (2013). Bioaktivitas tiga fraksinasi ekstrak biji suren terhadap mortalitas hama daun Eurema spp. Jurnal Penelitian Hutan Tanaman, Vol. 10 (2): 99 - 108.

Dendang, B., Sudomo, A., Raciman, E., \& Rusdi. (2007). Pengendalian hama ulat jengkal pada sengon dengan ekstrak daun suren dan cuka kayu. Wana Benih. Balai Besar Penelitian Bioteknologi dan Pemuliaan Tanaman Hutan. Yogyakarta.

Jayusman. (2006). Prospek dan keterbatasan suren (Toona spp). Warta P3HT Vol.1.

Lestari, F., \& Suryanto, E. (2010). Identifikasi jenis-jenis hama dan penyakit gaharu. Tidak dipublikasikan. Laporan Hasil Penelitian. Balai Penelitian Kehutanan Banjarbaru.

Lynn, O.H., Jang-Eok, Kim, \& Kyeong-Yeoll, Lee. (2012). Effect of azadirachtin on the development and gene expression of fifth instar larvae of Indianmeal moth, Plodia interpunctella. Journal of Asia-Pacific Entomology, 15: 101 - 101. 
Miller, J.R., \& Strickler, K.L. (1984). Finding and accepting host plants. Dalam: Chemical ecology of insects. Bel W.J., Carde R.T., editor. Massachusetts; Sinauer, Sunderland. p 127 - 157.

Prijono, D. (1999). Penuntun praktikum pengujian insektisida. Jurusan Hama dan Pe- nyakit Tumbuhan. Fakultas Pertanian Institut Pertanian Bogor. Bogor.

Tome, H.V.V., Martines, J.C., Correa, A.S., Galdino, T.V.S., Picanco, M.C., \& Guedes, R.N.C. (2013). Azadirachtin avoidence by larvae and adult females of the tomato leafminer Tuta absoluta. Crop Protection, 46: 63-69. 